\title{
EREBEA
}

Revista de Humanidades

y Ciencias Sociales

Núm. 7 (2017), pp. 13-40

ISSN: 0214-0691

\section{Prácticas de DisidenCIA: OLIGaRQUías URbanas Y JESUITAS EN LAS VILLAS COMERCIALES VASCAS EN EL PERÍODO ALTOMODERNO}

\author{
Rosario Porres Marijuán \\ Universidad del Pais Vasco/Euskal Herriko Unibertsitatea
}

Susana Truchuelo García

Universidad de Cantabria

Resumen

La instalación de la Compañía de Jesús en las principales villas comerciales del País Vasco fue compleja y conflictiva, llevándose a la práctica, efectivamente, tras reiterados conflictos y enfrentamientos. En este trabajo se reflexiona en torno a este complejo proceso, en un contexto de fuerte confesionalización y de intenso comercio atlántico, valorando la influencia en estas dinámicas de disidencia y conflicto de los objetivos espirituales y de adoctrinamiento de la Compañía y de los intereses financieros y comerciales, en los que coparticipaban jesuitas y unas elites mercantiles vascas católicas pero con fuertes vínculos en el comercio internacional pluriconfesional.

\section{Palabras Clave}

Compañía de Jesús; Comercio; Religión; Motín; País Vasco; Jesuitas.

Fecha de recepción: 16 de mayo de 2017

Fecha de aceptación: 13 de nov. de 2017

\section{Abstract}

The establishment of the Company of Jesus in the main commercial towns of the Basque Country was a complex and conflictive process. This essay takes into consideration those three processes, developed in a context of vivid confessionalism and active Atlantic trade, focusing on the role played in the conflict by both Jesuits' spiritual and indoctrination objectives and the targets of the Catholic Basque mercantile elite with strong links in the international and multi-confessional trade.

\section{KEYWORDS}

Company of Jesus; trade; religion; mutiny; Basque Country; Jesuits.

${ }^{*}$ Esta investigación se integra en el proyecto HAR2015-64014-C3-1-R (CULTURBAN) del Ministerio de Economía y Competitividad del Gobierno de Espańa, cofinanciado con fondos europeos del programa FEDER. Las autoras forman parte asimismo del Grupo de Investigación del Sistema Universitario Vasco IT896-16, Sociedad, poder y cultura (siglos XIV a XVIII). 

La instalación de nuevas órdenes religiosas en los marcos urbanos de la Península Ibérica, lejos de ser una práctica cotidiana exenta de problemas, constituyó en algunas villas en los siglos XVI y XVII una cuestión generadora de fuertes tensiones. En concreto, la Compañía de Jesús tuvo serias dificultades para establecer colegios en algunas villas y ciudades y, un poco por todas partes, su implantación llegó acompañada de altercados sociales. Alcalá, Zaragoza, Medina del Campo, Burgos, Palencia Toledo, o Pamplona son algunos de los muchos ejemplos que podrían traerse a colación aquí1. Como en esos y en otros muchos entornos urbanos, también en las villas y las ciudades vascas más relevantes y dinámicas de la época moderna el clero autóctono les fue hostil, por sus diferencias ideológicas e intelectuales, y seguramente mucho más por razones económicas y sociales. Una orden sin claros recursos con los que mantenerse, dotada -eso sí- de privilegios fiscales, con una trayectoria docente basada en la gratuidad y apoyada en una metodología superior a la que aplicaban otros ámbitos de enseñanza... era demasiada competencia ${ }^{2}$. Además, su afán por situarse en el centro de los núcleos urbanos y su fama de acumuladores de bienes, no les hacía buenos compañeros de viaje para las demás comunidades religiosas; menos aún, si tenían que compartir las aportaciones de los fieles. De ese modo, también en tierra del fundador se rechazó reiteradamente la instalación de la Orden en sus recintos urbanos. Múltiples causas convergieron en estas dinámicas de conflicto, como veremos a lo largo de este trabajo, de naturaleza económica, social y, sobre todo, política, que determinaron el fracaso final de gran parte de estas tentativas durante el siglo XVI y principios del siglo XVII ${ }^{3}$.

1 T. Egido (coord.), Los jesuitas en España y en el mundo hispánico. Madrid: Marcial Pons Historia, 2004, pp. 58 y ss.

2 R. Kagan, Universidad y sociedad en la España Moderna. Madrid: Tecnos, 1981, pp. 95-96; B. Bartolomé Martínez, "Las escuelas de primeras letras", en B. Bartolomé Martínez (dir.): Historia de la acción educadora de la Iglesia en España. Madrid: Biblioteca de Autores Cristianos, 1997, vol. I, pp. 612-630.

3 En Bilbao necesitaron sesenta años de maniobras políticas y algunas convulsiones sociales hasta recibir licencia para fundar en 1604 después de cuatro intentos fracasados; en San Sebastián otros tantos hasta lograrlo en 1627; en Orduña también les costó lo suyo, a juzgar por los diecisiete años de vacilaciones que precedieron a su instalación en esa ciudad aduanera a partir de 1683 . Finalmente, en Vitoria fueron precisos ocho intentos salpicados a lo largo de doscientos años para alcanzar su objetivo en 1751, con apenas tiempo ya de asentarse antes de que el monarca decretase la expulsión. R. Porres Marijuán, "Maniobras políticas y convulsión social en la aproximación de 
La Orden de San Ignacio de Loyola, fundada en 1534 e instalada en España desde 1547 había iniciado pronto un proceso de expansión vinculado al deseo de difundir el programa tridentino y su nuevo marco de religiosidad, bajo el impulso de los grupos dirigentes. La instalación de nuevos colegios en marcos urbanos que facilitaran la tarea de instrucción del nuevo Instituto ignaciano contaba con el apoyo económico de concretos fundadores y grupos de poder cortesanos. No era casualidad que los jesuitas se decantaran por introducirse en las principales villas comerciales del País Vasco, en particular en sus puertos marítimos más dinámicos y en las ciudades interiores de Vitoria y Orduña, sedes ambas de las principales aduanas del llamado Distrito Aduanero de Cantabria, centros de distribución de mercancías extranjeras por Castilla, Navarra y Aragón y, desde luego, núcleos de encuentro y negociación de capital dinerario. Pero, al mismo tiempo, todos ellos eran centros de información. De hecho, está constatado el interés que tenían los jesuitas en el comercio, nacional e internacional ${ }^{4}$. A pesar de ser en teoría una orden de clérigos regulares destinados al trabajo apostólico, y del obligado voto de pobreza y las prohibiciones sobre la propiedad, los padres ignacianos se ocuparon activamente en asuntos mercantiles, proceder que representaba una forma realista de enfrentarse a los problemas administrativos de su Orden, aunque les valiera las críticas de particulares y de las otras comunidades religiosas que la contemplaron más como una corporación mercantil que como una espiritual'5 . De ahí vendrían las especulaciones sobre su excesivo afán por acumular posesiones y el germen de cierto sentimiento anti-jesuita que se iría extendiendo con la misma velocidad que lo hacía el nuevo instituto. También es conocida su aspiración paralela por introducir su influencia en espacios poblados, ricos y dinámicos, lo que les permitía acceder a cuantiosas mandas pías y donaciones para la ejecución de su proyecto confesional. Eso sin olvidar la importancia que para la Compañía representaba el ir tejiendo su propia red jesuita, más efectiva incluso que las propias redes imperiales -en palabras de Martínez-Serna-, con un sistema que nadie podía igualar, ni las otras órdenes, ni la iglesia diocesana, ni siquiera los oficiales reales ${ }^{6}$.

los jesuitas al País Vasco en el siglo XVI" en J. Martínez Millán, H. Pizarro y E. Jiménez Pablo (coords.): Los jesuitas. Religión, politica y educación (siglos XVI-XVIII). Madrid: Universidad de Comillas, 2012, t. II, pp. 1073-1100; "Propiedades eclesiásticas en una ciudad aduanera: los jesuitas en Orduña, 1689-1767", en Hispania Sacra, LXIV, 2012, pp. 309-343; T. Benito Aguado, "La resistencia al asentamiento de los jesuitas en el País Vasco: Vitoria, 1583-1751" en R. Porres Marijuán (ed.): Poder, resistencia y conflicto en las Provincias Vascas, siglos XV-XVIII. Bilbao: UPV/EHU, 2001, pp. 48 y ss.

4 R. Porres Marijuán, "Las redes mercantiles atlánticas y la instalación de los jesuitas en Bilbao, 1551-1604" en I. Dubert y H. Sobrado (eds.), El mar en los siglos modernos. Santiago de Compostela: Xunta de Galicia, 2009, t. I. pp. 499-512.

5 C.-U. Montiel, "Los escenarios políticos del Procurador Diego Ignacio Fernández: Corte, misión y aduana", en Martínez Millán et alii, Los jesuitas, t. I, p. 327.

6 J. G. Martínez-Serna, "Procurators and the Making of the Jesuits", en B. Bailyn y P. L. De- 
La Compañía de Jesús constituía una red cuya unidad básica fue la Provincia (las provincias atlánticas de la orden que incluían a España, Portugal los Países Bajos, Francia e Inglaterra, con sus respectivos imperios en el Nuevo Mundo) a través de la cual los ignacianos distribuían mercancías diversas, libros, dinero (pagos en plata destinados a mantener la burocracia de la orden, las misiones, realizar préstamos, etc.), a sus misioneros y, principalmente, información ${ }^{7}$. La circulación de cartas, informes, instrucciones y noticias, siguiendo unos cánones perfectamente diseñados desde la propia Compañía -en lo que algunos autores reconocen como un elemento esencial de la naciente cultura de la noticia en la Europa moderna ${ }^{8}$, desempeñó un enorme papel, no ya en la expansión del nuevo instituto y en la coordinación a distancia de los esfuerzos jesuitas, sino en el gobierno de la Compañía misma, al permitir que sus iniciativas se desarrollasen con un grado extraordinario de cohesión y de uniformidad. En ese sentido, además de con otros objetivos, los colegios se erigieron como nodos estables por medio de los cuales coordinar la comunicación a distancia ${ }^{9}$.

En esta línea, en el desarrollo de la Provincia jesuítica de Castilla, al tiempo que levantaba diversos colegios en el interior de la meseta -Valladolid (1545), Salamanca (1548), Burgos (1551), Medina del Campo (1551-57), etc.- la Compañía buscó reiteradamente su salida al mar, interesándose en los principales puertos del Cantábrico como Santander, Bilbao, San Sebastián, entre otros, y en el control de las rutas aduaneras en sus núcleos esenciales como Vitoria y Orduña. Además de lo señalado, y de su importancia económica y financiera, los núcleos urbanos vascos contaban con otras ventajas: una situación geográfica privilegiada en zona de frontera, unos regímenes jurídicos propios, una abundante y bien formada infraestructura mercantil y humana, recursos, sin duda alguna, importantísimos para las aspiraciones y formas de obrar de la Compañía en aquellos momentos de convulsiones religiosas, económicas, políticas y militares que tuvieron como escenario el espacio atlántico desde mediados del $\mathrm{XVI}^{10}$. Así, el interés por allegarse a la tierra del fundador de la Compañía fue tan notable que, a pesar de los muchos problemas que tuvieron que afrontar, en

nault, (eds.), Soundings in Atlantic History: Latent Structures and Intellectual Currents, 1500-1830. Cambridge, MA: Harvard University Press, 2009, pp.181-209.

7 F. Palomo, "Misioneros, libros y cultura escrita en Portugal y España durante el siglo XVII", en C. Castelnau-L'Estoile et alii (eds.), Missions d'évangélisation et circulation des savoirs (XVIeXVIIIe siècle). Madrid: Casa de Velázquez, 2011, pp. 131-150.

$8 \mathrm{~J}$. Petitjean, "Mots et pratiques de l'information. Ce que aviser veut dire (XVIe- XVIIe siècles)", en Mélanges de l'École française de Rome, 122 (2010), pp. 107-121.

9 P. Nelles, "Chancillería en colegio: la producción y circulación de papeles jesuitas en el siglo XVI", en Cuadernos de Historia Moderna, 2014, anejo XIII, p. 50 y ss.

10 S. Truchuelo García, "Fronteras marítimas en la Monarquía de los Habsburgo: el control de la costa cantábrica", en Manuscrits. Revista de Història Moderna, 32 (2014), pp. 33-60 https://doi. org $/ 10.5565 / \mathrm{rev} / \mathrm{manuscrits} .47$. 
ella acabarían estableciendo 9 de los 32 colegios que se levantaron en la Provincia jesuítica de Castilla, es decir, el 28\%.

Pero en sus aspiraciones religiosas y económicas la Orden ignaciana no estaba sola, sino que debía competir con otras comunidades religiosas que ya estaban asentadas en las mismas urbes, particularmente las órdenes mendicantes de franciscanos y dominicos, de gran predicamento en la zona. Con ellas se desarrollaron abiertos enfrentamientos a finales del siglo XVI y principios del siglo XVII, como veremos en este trabajo, al igual que con las oligarquías urbanas con quienes dichas comunidades religiosas estaban perfectamente imbricadas. Es evidente que, desde sus inicios, la Compañía buscó el apoyo de aquellos a quienes el tejido social urbano percibía como sus líderes y gobernantes naturales, pues a través de ellos lograrían no sólo los recursos económicos precisos para iniciar su andadura, sino también ser aceptados por una comunidad que solía mimetizar los comportamientos nobiliarios de sus dirigentes. Como en su día señaló Julián Lozano, en ese tipo de aproximaciones los ignacianos tenían diseñada una estrategia muy bien definida en la que hacían uso de tres grandes herramientas: el control de las conciencias a través de la dirección espiritual; el manejo de los negocios seculares al servicio de los poderosos como una forma más de ganar prestigio; y la formación de una tupida red clientelar. En ello, también la creación de colegios se convirtió en el centro de su estrategia, concebidos estos más como centros de adoctrinamiento de la sociedad que como meras entidades docentes ${ }^{11}$.

En suelo vasco nunca faltaron valedores a la Compañía de Jesús. Importantes damas, grandes comerciantes, clérigos, funcionarios regios, indianos y militares, no siempre autóctonos, ofrecieron parte de sus bienes para financiar el levantamiento de colegios en la tierra del fundador de la Orden. Pero para fundar se precisaba algo más que los capitales privados y los planes de la Compañía. Había que empatizar con las comunidades receptoras, y sobre todo con sus dirigentes, tanto laicos como eclesiásticos. Y es aquí donde reiteradamente surgieron los problemas, los enemigos, a los que no cabe significar como meros "apasionados e ignorantes mostrando sus antipatías a los hijos de Ignacio" ${ }^{12}$, como los definió en su día Malaxechevarría, sino como los componentes de una bien organizada oposición, dirigida por hombres doctos que se movían por intereses de diverso calado, ya personales, ya de grupo. Este último aspecto ya nos avisa claramente de que las oligarquías urbanas no siempre adoptaron una postura uniforme ante la institución ignaciana.

11 J. Lozano Navarro, La Compañia de Jesús y el poder en la España de los Austrias. Madrid: Cátedra, 2005, pp. 32-35.

12 J. Malaxecheverría, La Compañia de Jesús por la instrucción del País Vasco en los siglos XVII y XVIII. San Sebastián: Librería e Imprenta San Ignacio de Loyola, 1926, pp. 53-54. 


\section{LOS JESUITAS EN LOS INTERESES DEL PODER EPISCOPAL CALAGURRITANO}

Entre los partidarios del nuevo instituto, las primeras iniciativas partieron de la Iglesia, en concreto del titular de la sede episcopal de Calahorra, el obispado que con el de Burgos se repartía la jurisdicción eclesiástica sobre territorio vizcaíno y alavés. Por encima de su amistad con Ignacio de Loyola, don Bernal Díaz de Luco -bien conocido por sus reformas y su participación en Trento- contempló en los primeros jesuitas un instrumento con el que atajar el mal estado de la iglesia vizcaína y su clero, fruto de siglos y siglos de inoperancia episcopal a causa de la pervivencia del patronato laico sobre gran parte de las parroquias ${ }^{13}$, y de la prohibición expresa recogida por el Fuero de que el obispo actuara en la tierra ${ }^{14}$. La prohibición foral atendía en parte al temor de que los prelados se inmiscuyeran en los enfrentamientos banderizos, pero también a razones de índole económica: el interés de los patronos laicos en dominar las iglesias y cobrar sus diezmos y primicias, mientras clérigos y fieles se veían libres del pago de la limosna, el subsidio, el sello y la visita canónica al obispo. A través de los patronatos sobre las iglesias, - tanto los diviseros como los mercedarios de los que se fueron apropiando por vías diversas- los linajes hidalgos habían ido tejiendo redes coherentes, por medio de las cuales se articuló el poder de los parientes mayores en las comunidades vecinales de determinadas villas, anteiglesias o comarcas ${ }^{15}$. No en vano, los derechos de patronazgo suponían de facto una fiscalización de la organización social y productiva de la comunidad en beneficio del patrono, ya que a través de los mismos controlaban no ya la vida religiosa, sino el tráfico comercial, la explotación agraria y la jerarquía social de la misma ${ }^{16}$.

Además, la pervivencia del patronato laico sobre las iglesias a manos de los hidalgos (o de las villas) limitaba, no ya las rentas del prelado, sino su capacidad

13 Solo se aceptaba una jurisdicción episcopal mermada pues apenas tenía capacidad para juzgar a laicos en los casos contemplados en el llamado Capitulado de Astudillo, pero no en pleitos relacionados con las iglesias señoriales, que se entenderían en foros civiles. A. de Mañaricúa, "Problemas religiosos en la Vizcaya de los siglos XIV y XV, régimen monasterial, jurisdicción episcopal y decadencia religiosa", en La sociedad vasca rural y urbana en el marco de la crisis de los siglos XIVy $X V$. Bilbao: Diputación Foral de Vizcaya, 1975, pp. 255-256.

14 El patronato laico era abundante en Vizcaya y Guipúzcoa, no tanto en Álava donde sólo se conservó prioritariamente en el norte de la provincia. E. Catalán, El precio del Purgatorio. Los ingresos del clero vasco en la Edad Moderna. Bilbao: UPV/EHU, 2000, pp. 29 y ss; Véase igualmente Á. Larrea Beobide, El patronato laico vizcaíno en el Antiguo Régimen. Bilbao: Edicionesbeta, 2000.

15 E. Catalán, "La pervivencia del derecho patrimonial en la Iglesia vasca durante el feudalismo desarrollado", en Hispania, 190, 1995, p. 567.

16 A. Dacosta, "Ser hidalgo en la Bizkaia bajomedieval: fundamentos de un imaginario colectivo" en I. Reguera y R. Porres (coords.): Poder, pensamiento y cultura en el Antiguo Régimen. San Sebastián: RSBAP, 2002, pp. 22-23; J. R. Díaz de Durana, "Patronatos, patronos, clérigos y parroquianos. Los derechos de patronazgo sobre monasterios e iglesias como fuente de renta e instrumento de control y dominación de los Parientes Mayores guipuzcoanos, siglos XIV a XVI", en Hispania Sacra, 50 (1998), pp. 505-506. 
para intervenir en el nombramiento de curas y beneficiados y, por tanto, para controlar la formación y los modos de vida de los eclesiásticos. De ese modo, parcialmente privada de su principal fuente de riqueza, el diezmo, junto con la designación de parte de sus bases a través del derecho de presentación, la clerecía vasca se había convertido en un apéndice de la nobleza, carente de poder y la mayoría de las veces incapacitada para ejercer su ministerio pastoral; y, sin duda alguna, muy asimilada a la división banderiza por la que aquella se caracterizaba. Lo mismo podría decirse de las oligarquías de las villas. El resultado de todo ello era una masa abundante de clero sirviendo las iglesias, pero poco formado y pobre - por la cortedad de las rentas que les daban sus patronos laicos-, autóctono y con modos de comportamiento y medios de vida similares a los del pueblo, con el cual mantenía una gran complicidad ${ }^{17}$. El amancebamiento de los clérigos vascos, que tanto preocupó al episcopado pero también a la Corona ${ }^{18}$, y en cuya erradicación ambos poderes sintieron imprescindibles a los jesuitas, era consecuencia muy directa de este estado de cosas. Lo mismo puede decirse de otros comportamientos nada acordes con el espíritu tridentino. El ejercicio del sacerdocio, entendido como un bien patrimonial, vinculó hasta tal punto a la nobleza y a la Iglesia que era difícil establecer una línea divisoria nítida entre sus miembros. A veces era complicado discernir entre su condición de clérigos o su condición de caballeros.

A lo largo de los siglos XVI y XVII las autoridades diocesanas trataron de perfilar los roles de ambos grupos sociales, inculcando a los clérigos actitudes claramente diferenciadas de sus parientes, los caballeros. Esa separación del poder civil y religioso se veía indispensable, no sólo para desempeñar correctamente las funciones pastorales, sino para reforzar la autoridad del Ordinario entre los eclesiásticos que se encontraban bajo el régimen de patronato. También lo era que renunciasen a la actividad nobiliaria por excelencia, el ejercicio de la guerra, y para que erradicaran una costumbre muy arraigada entre los clérigos: la transmisión hereditaria de los curatos y bienes eclesiásticos. La estructura patrimonial de la Iglesia dificultaba enormemente la erradicación de esta práctica en cuanto se consideraba como un bien familiar y por lo tanto susceptible de ser transmitido en herencia. La consideración de la iglesia como un bien propio, se perpetuó a través de la designación de beneficiados y clérigos entre los familiares del patrón, o de algún miembro del cabildo, sin que los obispos hallasen un medio eficaz

17 J. Muro Abad, "El clero diocesano vasco en los siglos XV y XVI: una imagen" en E. García (dir.): Religiosidad y sociedad en el País Vasco, siglos XIV-XVI. Bilbao: UPV/EHU, 1994, pp. 74 y ss.

18 M. Álvarez Urcelay, "Iglesia, moralidad y justicia en Guipúzcoa, siglos XVI-XVIII" en R. Porres Marijuán (coord.): Entre el fervor y la violencia. Estudios sobre los vascos y la Iglesia (siglos XVIXVIII). Bilbao: UPV/EHU, 2015, pp. 99-130; I. Reguera, "Violencia y clero en la sociedad vasca de la Edad Moderna”, en Porres Marijuán, Entre el fervor..., pp. 131-186. 
para eliminar el problema. Sólo a partir de los años cuarenta del siglo XVII esta cuestión mostraría visos de comenzar a remitir ${ }^{19}$.

Así pues, entre otros objetivos, sería todo ese engranaje socio-económico y político el que la Compañía de Jesús, una orden nueva y desarraigada del territorio y sus vicisitudes, estaría llamada a desactivar. Lograrlo por la vía del clero autóctono era poco menos que imposible. Éste se hallaba demasiado implicado en todo ese engranaje social y, tanto o más, en el económico que le acompañaba. Incluso las órdenes mendicantes que imperaban en el ámbito urbano estaban demasiado comprometidas en este mismo contexto, sobre todo los franciscanos, cuyos vínculos con la sociedad vasca se fue apuntalando a través de su estrecha relación con los mercaderes, incluso con los que vivían entregados al comercio ultramarino, en Flandes, en Sevilla o en Indias ${ }^{20}$. Establecer una orden nueva, capaz de romper o de actuar en ese entramado era complicado y lo fue durante mucho tiempo. Por ello, aunque don Bernal llamó a las puertas de importantes personajes de la Corte, deseoso de que el monarca concediese algún patronazgo a la Compañía en Bilbao, no hizo sino cosechar un rotundo fracaso y avivar la voz enemiga del clero local. Su gran error fue, precisamente, ofrecer a los jesuitas la sede de Begońa cerca de Bilbao, muy del gusto de Ignacio de Loyola ${ }^{21}$, pero que suponía una nueva distribución del patronato y una amenaza a los componentes del cabildo eclesiástico bilbaíno que la controlaba; y que conllevaba, desde luego, una prueba manifiesta de intromisión del obispo en los asuntos eclesiásticos de la Villa y del Señorío. Aunque el encargado de hacer las gestiones fue el mismísimo Francisco de Borja, como en su día señaló Labayru nada pudo hacer ante la oposición del patrono, del cabildo de Bilbao y del pueblo begoñés.

LOS INTERESES DE LA CORONA Y EL IMPULSO DEL MUNDO MERCANTIL EN LA ÚLTIMA DÉCADA DEL QUINIENTOS

Aunque a fin de cuentas durante su episcopado solo había conseguido fundar un colegio en Ońate (1551), las ideas de Díaz de Luco sin embargo no cayeron en saco roto pues eran compartidas por la Corona, que atendía a sus propios intereses, no tanto medidos en la erradicación del patronato laico sino más bien en la recuperación de aquellos patronatos que, siendo reales, habían sido usurpados por la nobleza o las villas. Su objetivo era recompensar con ellos la fidelidad de familias linajudas en ascenso -como los Lezama o los Idiáquez- de probada lealtad a la Corona y afiliadas a la causa de pacificar el territorio y desactivar a los grandes

19 Sobre estas cuestiones véase E. Catalán, "El clero rural vasco durante la Edad Moderna”, en Porres Marijuán, Entre el fervor..., pp.17-56.

20 J. R. Díaz de Durana y A. Otazu, El espiritu emprendedor de los vascos. Madrid: Sílex, 2008, pp. 132-134.

21 S. Echevarría, Historia de Nuestra Señora de Begoña, [1 ${ }^{\text {a }}$ ed. 1892]. Bilbao: Ed. Amigos del libro vasco, 1985, p. 126. 
linajes banderizos, como los Butrón y los Avendaño, cuyas zonas de influencia dominaban importantes vías de comunicación, en el interior y en la salida al mar, ferrerías, villas armeras, etc. Por ello, en 1591, enarbolando de nuevo el tema del amancebamiento y la vida licenciosa del clero vizcaíno, poco acordes con las doctrinas tridentinas, Felipe II recomendó la designación de un censor, con jurisdicción desde Vitoria hasta Laredo, Bilbao y San Sebastián, encargado de solucionar la cuestión. Habría de ayudarse en ello de varios jesuitas, por lo que autorizó la fundación de un colegio en Vitoria, donde ya habían fracasado en 1577 y 1583 a causa de la oposición de sus autoridades locales, mucho más cohesionadas que las de Bilbao en este tema. Para ello, enarbolaron una cédula real que dejaba en sus manos todo lo referente a las fundaciones eclesiásticas, en medio de una fuerte polémica sobre la limpieza de sangre que, por aquel entonces, los jesuitas aún no respetaban en su Orden ${ }^{22}$. Además, aquellas elites estaban más a otras cosas, pues venían reclamando una diócesis para Vitoria en caso de que, como se temía, la de Calahorra llegase a dividirse en $\operatorname{dos}^{23}$.

Volviendo a los años noventa del siglo XVI, Felipe II se había reconciliado con la Compañía, a la que -al igual que su padre- no era muy afecto. Aquella había superado sus propias rencillas internas que la habían atenazado desde los años setenta -que a punto estuvieron de costarle una escisión-, y el resentimiento que despertó tras del triunfo del partido castellanista en la Corte del que se había impregnado el propio monarca. La Compañía lograba recobrar la confianza regia, mientras la institución salía reforzada de la Congregación General de la Orden que se celebraría en 1593 con una nueva ideología y práctica religiosas ${ }^{24}$. Esto les reconciliaba con los intereses políticos de la Monarquía Católica, aunque al mismo tiempo confirmaba su dependencia directa del Papa. De todos modos, la Corona tenía más interés que nunca en allanar estos territorios fronterizos del norte, en un momento en el que ya había decidido intervenir en los asuntos franceses, tras la muerte del último monarca Valois, Enrique III, en 1589; en que los genoveses cobraban de nuevo protagonismo en las finanzas regias y las leyes del embargo y el contrabando estaban en su punto álgido. Desde luego, el rey no era

22 Cédula Real, Madrid 23-04-1577. R. Porres Marijuán y T. Benito Aguado, "El estatuto de limpieza de sangre y sus repercusiones en Vitoria en tiempos de Felipe II", en Hispania, LX/2, 2000, p. 515.

23 R. Porres Marijuán, "De la Hermandad a la Provincia (siglos XVI-XVIII) en A. Rivera (dir.): Historia de Álava. San Sebastián: Ed. Nerea, 2003, pp. 263-264. Cuando en 1576 se oyeron rumores sobre una posible división del obispado imponiendo otra sede en Santo Domingo de La Calzada, las autoridades alavesas presentaron la candidatura de Vitoria por considerarla mejor situada y capacitada en la lucha contra la herejía. Fue sin embargo una aspiración que Vitoria arrastró durante siglos y que no lograría hasta 1861.

24 J. Martínez Millán, “Transformación y crisis de la Compañía (1578-1594), en F. Rurale (dir.), I religiosi a Corte. Teología, politica e diplomazia in Antico Regime. Roma: Bulzoni, 1998, pp. 128-129. 
ajeno a la trascendencia de las provincias vascas de cara a la política exterior que durante toda la segunda mitad del siglo XVI y primeros ańos del XVII mantuvo la Corona, con conflictos abiertos con las Provincias Unidas y más tarde con Inglaterra y Francia. También era consciente de las consecuencias que la política de embargos hacia los enemigos de la Monarquía tuvieron en el comercio atlántico, que terminaron por acogotar a un sector mercantil y financiero castellano, ya en crisis antes de que mediara el siglo, dejando su control en manos de extranjeros, al tiempo que se incrementaba el contrabando. Consecuentemente, el comercio ilegal se prodigaba en la zona, amparado en el particular régimen jurídico, fiscal $\mathrm{y}$ aduanero de las provincias vascas, y en la aquiescencia de sus gentes; $y$ hasta de sus autoridades locales y provinciales ${ }^{25}$; un régimen protagonizado igualmente por extranjeros y un comercio ilegal al que la Corona buscaba desesperadamente poner freno o, al menos, incorporar parte de sus beneficios.

Será en ese foro donde jugarán sus cartas tanto los defensores como los enemigos de que los jesuitas se instalasen, en aquel momento en Bilbao, tras la nueva negativa de los vitorianos. Se disponía de un cuantioso legado que, seguramente no por casualidad, procedía del entorno financiero del propio rey, en concreto de las familias de mercaderes-banqueros de origen genovés Centurión y Spínola. Eran 1.800 ducados de renta anual de juro que doña Jhoana Magdalena Centurión, la viuda de Agustín Spínola -asentista y arrendatario de varias rentas reales, entre otras la de los derechos de sacas de lana- legó en 1590 para fundar un colegio cuya ubicación debía decidir el General de la Orden. De los trámites del legado se encargaría el cuñado de doña Jhoana, nada menos que Ambrosio Spínola, el asentista genovés que durante los años siguientes más crédito aportó a Felipe $\mathrm{II}^{26}$.

Una vez que este legado quedó libre por el rechazo de las autoridades de Vitoria, la circunstancia fue aprovechada por un conocido comerciante y corredor de seguros bilbaíno asentado en Burgos, Andrés de Larrea -que conocía bien a los Spínola y los Centurión- que desde 1577 se había convertido en el estandarte de los defensores de la causa ignaciana en Bilbao. Hijo de un armador portugalujo, hizo sus primeras incursiones mercantiles en los Países Bajos al servicio de importantes casas comerciales burgalesas, como los Bernuy -conocidos filojesuitas- y también para los Ruiz medinenses. Establecido más tarde en Sevilla, Larrea desarrolló una fulgurante actividad al abrigo de la Carrera de Indias, traficando con mercurio (mediante un asiento concedido por la Corona en 1561) y, sobre todo, con esclavos negros a través de algunas compañías, como la de los mercaderes

25 S. Truchuelo García, "La represión del fraude comercial en el litoral vasco en el período altomoderno", en Sancho el Sabio. Revista de Cultura e Investigación Vasca, 23 (2005), pp. 11-34; A. Angulo Morales: "El mundo al revés: la visión del contrabando por los representantes de la Hacienda real y Pública en el País Vasco", en Revista Sancho el Sabio, 7 (1997), pp. 78-85.

26 C. J. De Carlos Morales, Felipe II: el Imperio en bancarrota. La Hacienda real de Castilla y los negocios financieros del Rey Prudente. Madrid: Dilema, 2008, pp. 253 y ss. 
castellanos Del Río, y también al servicio del banquero y mercader de esclavos de origen vizcaíno Pedro de Morga ${ }^{27}$; todo ello le permitió contactar con los más importantes hombres de negocios y financieros de la época, en particular los genoveses. Tras la fuerte crisis que Sevilla vivió en los ańos sesenta, centró su carrera en Burgos donde destacó en la denominada red bilbaína de seguros con corredores en las principales plazas comerciales y financieras del norte de Europa, y en la que destacaron otros bilbaínos, como los Agurto de notoria inclinación filojesuítica ${ }^{28}$.

En Burgos, Andrés de Larrea ocupó además importantes cargos en el Consulado y el Ayuntamiento, en un momento en que esa ciudad cobró un notable impulso en el organigrama eclesiástico de la Monarquía desde que, en 1572, estableció en ella un Arzobispado al que asignó como sufragánea, entre otras, la diócesis calagurritana. Esto significaba que era en Burgos donde se cocían los más importantes asuntos de la diócesis. En esa ciudad, Larrea vivió de cerca la bancarrota de 1575 -que sufrió en sus propias carnes-, supo de la expulsión de las tropas españolas de Amberes en 1577 y la toma de esta ciudad y Bruselas por el Príncipe de Orange, y de la aprobación del "medio general" por el rey en ese mismo año. También conoció sus efectos sobre las más importantes familias del comercio burgalés que hasta no hacía mucho venían controlando el mercado europeo.

Desde Burgos, Larrea, considerado como un vizcaíno ilustre por las autoridades del Señorío, se dedicó a prestarles algunos servicios, entre los cuales consideró siempre como el más importante el de acercar a la Compañía a Bilbao. Desde 1592, y durante los doce ańos siguientes, Larrea se carteó repetidamente con las autoridades bilbaínas, aunque hubo de bregar con la alternancia en el Ayuntamiento entre partidarios y detractores de la causa ignaciana ${ }^{29}$. La oposición, pertinaz, se apoyaba en un doble argumento: el primero, la fama de especuladores que para entonces arrastraban los jesuitas; el segundo, que una decisión tan importante para la Villa debía tomarse en concejo abierto. Larrea nunca dejó de llamar a las puertas del Regimiento, en el que siempre contó con amigos dispuestos a dar alas a su causa. Pero el legado de la señora Centurión acabaría por perderse, destinándose al colegio de la villa guipuzcoana de Vergara en 1593. Un año después, Larrea pretendió otro legado para Bilbao, el de los 2.000 ducados que dońa Magdalena de Ulloa - la llamada limosnera de Dios, que había criado a don Juan

27 J. Ortiz Arza, "Negreros vascos al servicio de la Inquisición en la Sevilla del siglo XVI: la Compañía del vizcaíno Pedro de Morga", en Porres Marijuán, Entre el fervor..., pp. 299-337.

28 J.-P. Priotti, Bilbao y sus mercaderes en el siglo XVI. Génesis de un crecimiento. Bilbao: Diputación Foral de Bizkaia, 1984, pp. 192 y ss.

29 Esta cuestión ha sido tratada minuciosamente en R. Porres Marijuán, "La Compañía de Jesús en las ciudades vascas. Intrigas políticas y agitación social en la fundación de los colegios de Vitoria y Bilbao, 1577-1604” en E. García Fernández (ed.), Bilbao, Vitoria y San Sebastián: espacios para mercaderes, clérigos y gobernantes en el Medievo y en la Modernidad. Bilbao: UPV/EHU, 2005, pp. $185-250$. 
de Austria- tenía destinado para Santander, a donde finalmente fue dirigido. Las intrigas políticas de Larrea y su perseverancia desde Burgos acabarían por movilizar a la clerecía bilbaína y a muchos vecinos partidarios de cerrar las puertas de la Villa a los jesuitas. Ni siquiera la mediación del todopoderoso Juan de Idiáquez en la Corte reforzó los propósitos de don Andrés, y en 1595 se denegó la fundación paralizándose toda la cuestión hasta 1600.

LA DIVISIÓN DE LA OLIGARQUÍA MERCANTIL BILbAÍNA ANTE LA COMPAÑía DE JESÚS

No obstante, es preciso insistir en que Larrea nunca actuó solo. Muy al contrario, sabemos que contó con grandes apoyos dentro y fuera de la Villa, entre otros Pedro de Agurto Gastańaga, el armador más importante de la Villa, y el clérigo Juan Ochoa de Larrea. Pero no se trataba sólo de individuos aislados unidos en su afección a la Compañía, sino de un conjunto de sujetos que tenían en común su trabajo como intermediarios en el puerto de Bilbao al servicio de importantes redes dominadas por mercaderes castellanos y banqueros genoveses que unían la meseta con las principales plazas del norte de Europa. En conjunto, se trataba de sujetos incardinados sobre todo en la amplia red mercantil compuesta por los Ruiz castellanos (Simón Ruiz en Medina del Campo y Andrés y Julián Ruiz en Nantes), o los Del Peso y De la Presa burgaleses, entre otros; una red en la que, como en todas las de entonces, los lazos familiares, la amistad, la confianza y la cohesión religiosa eran determinantes, y cuya actividad se extendía principalmente de Castilla a Lyon pasando por Bilbao y Nantes y de aquí a los Países Bajos. Se trataba, sin duda, de uno de los mayores ejes de intercambios del Atlántico europeo en el XVI, imprescindible para el envío del numerario llamado a mantener a flote los asientos hechos con destino al ejército de Flandes. Constituían redes muy vinculadas a la Compañía de Jesús tanto en sus tratos mercantiles como espirituales. Entre quienes apoyaron a Larrea en su objetivo de introducir a la Compañía en Bilbao, el que más y el que menos se movía en esos circuitos. Se dedicaban a la exportación de lana y a la importación de papel, lencería francesa y cera de Flandes al servicio de castellanos principalmente. Pero también a la saca de dinero, incluso al servicio de la propia Corona cuando así lo requería. Hablamos de la élite del comercio bilbaíno, los Del Barco, los Vitoria, los Nobia, los Catelinaga, los Bilbao La Vieja o los Agurto y, a estas alturas, incluso de sus vástagos, que se habían formado en el entorno de los Ruiz y que estaban regresando a causa de los problemas ocasionados por la desafección religiosa en Europa y los cambios ocasionados por la guerra. Fue precisamente la guerra la que propició el ascenso de otros bilbaínos que también se colocaron al lado de Larrea en su protección a los jesuitas. Se trataba de armadores y mercaderes que hicieron fortuna a través del servicio a la Corona y sus necesidades militares: los Lezama, por ejemplo, que monopolizaron el cargo de proveedor de las Armadas hasta 1625; o los Fuica, en particular Francisco, que sirvió como tenedor de la fábrica de los galeones del rey 
y fue veedor del Señorío, cuando menos desde 1602 hasta 1623, momento clave como se puede suponer por el gran auge cobrado por el contrabando.

¿Qué movía a este grupo a tan fuerte afección ignaciana? Larrea decía moverse sólo por el amor a su patria, vago principio al que supo dar también un contenido más prosaico, propio de una mentalidad mercantil como la suya, al valorar esos 20 ó 30 ducados anuales que dejarían todos aquellos padres que decidiesen enviar a sus hijos a estudiar con los jesuitas a Bilbao. No se olvidaba, claro está, de los méritos de la propia Orden. Incluso por encima de su labor pastoral, valoraba el que los jesuitas pudieran servir de referente para la sociedad bilbaína, por su fama de buenos conciliadores y especialistas en extirpar vicios como el amancebamiento. Y éstas eran condiciones muy plausibles y útiles en el enrarecido clima social que se vivía en Vizcaya, pues como señalaba Ochoa de Larrea, solían los jesuitas desvelarse por alcanzar la concordia entre pleiteantes "lo que aqui jamas se haze ni por frailes ni por legos, por sus paçiones y parcialidades apasionandose unos por $\operatorname{otros}^{\prime 30}$. Pero ni Larrea ni los suyos podían esconder el mayor de sus temores en aquel final de siglo: la masiva afluencia de extranjeros a Bilbao y al Señorío y los peligros religiosos que de ello se podían derivar. La propia Compañía de Jesús se veía a sí misma como un baluarte frente a las diferentes sectas que los extranjeros estaban intentando sembrar.

Cabe pensar, sin embargo, que se trataba de algo más que de una cuestión religiosa. Nada de lo que Bilbao pudo vivir en aquella segunda mitad de siglo fue ajeno al hecho de que la crisis económica -sobre todo la del sector lanero- y financiera, la guerra generalizada -con los Países Bajos (1566), Inglaterra (1585) y Francia (1595) - y la política de embargos aplicada para contener al enemigo, acabaran por entorpecer el tráfico mercantil en el Atlántico europeo y propiciando cambios extraordinarios en su control, al tiempo que impulsaban notablemente el contrabando. Las otrora pujantes colonias castellanas en las plazas comerciales de Europa se estaban desmantelando, mientras que un movimiento de expansión en sentido inverso, protagonizado por franceses, ingleses, holandeses y portugueses, pasó a acaparar una buena parte del comercio hispano. Se iban quebrando los lazos de solidaridad religiosa de las redes mercantiles, incluida la de los Ruiz, la peor consecuencia del problema religioso que había estallado en Europa y que afectó a las colonias castellanas asentadas en el extranjero: se vieron contagiadas por la Reforma protestante, produciéndose una fragmentación, no ya en el seno de las colonias, sino en el de las propias familias. Sucedió en Amberes, en Ruán, en Nantes, etc. Los negocios comerciales y financieros seguirían realizándose, pero de otra manera, porque el principio de la confianza se había quebrado ${ }^{31}$. En

30 Porres Marijuán, “Las redes mercantiles atlánticas...”, pp. 506-507.

$31 \mathrm{H}$. Casado Alonso, El triunfo de Mercurio. La presencia castellana en Europa, siglos XV-XVI. Burgos: Caja Círculo, 2003, pp. 181-182. 
medio de aquel marasmo, -agravado, y mucho, por las medidas políticas y financieras del monarca francés Enrique IV que acabaría por expulsar a los jesuitas de Francia en 1595-, a finales del siglo XVI algunos de los intermediarios bilbaínos de los Ruiz en las plazas europeas habían regresado a Bilbao o estaban en trance de hacerlo. El propio Simón Ruiz fallecerá en 1597. Hasta el mismo Andrés de Larrea dejará entonces su refugio burgalés para instalarse en Bilbao, donde hará carrera en el Consulado y en el Ayuntamiento en los primeros años del siglo XVII, lo que le permitirá implicarse aún más en su apoyo a la Compañía. De hecho, él fue uno de los primeros en recibirlos cuando acabaron instalándose en la villa.

En cierta manera, todo el mundo debía acomodarse a las nuevas circunstancias. En aquella etapa de cambios, muchos vizcaínos adaptaron sus negocios, se involucraron en el comercio americano y en el del Atlántico ibérico, y se dedicaron cada vez más a actividades de comisión y financieras, a la especulación ${ }^{32}$. Y, sobre todo, se fueron sometiendo a los operadores extranjeros, pues eran los nuevos dueños del comercio internacional. Bilbao fue llenándose de extranjeros, cuyas casas de comercio aumentaban por doquier. En los primeros años del siglo XVII más del $55 \%$ de las embarcaciones que arribaban anualmente a su puerto eran extranjeras. Franceses, holandeses, ingleses, flamencos e irlandeses se contaron entre los negociantes más activos de Bilbao, donde en 1603 ya sólo uno de cada dos vendedores era vizcaíno ${ }^{33}$; incluso había portugueses, de cuya presencia existen noticias tempranas, si bien se ha constatado que gustaban de ocultar su origen. Los componentes de las redes señaladas se resistían a desaparecer y procuraban combatir a los extranjeros intrusos. Por el contrario, quienes se estaban adaptando a la nueva realidad en el reparto del pastel necesitaban a los extranjeros.

La intromisión de los extranjeros tuvo mucho que ver también con el avance del contrabando que derivó del desbaratamiento de las colonias de Flandes, en particular la de Amberes. Frente a las prohibiciones regias, los extranjeros buscaron complicidad entre los vizcaínos, estableciendo con ellos no sólo lazos económicos sino incluso familiares. Porque, a no tardar, entroncaron con familias bilbaínas, incluso con las de mayor lustre como los Leguizamón, Zurbarán y Arbolancha. En esas condiciones la Corona tenía muy difícil mantener su política exterior, no solo la militar, la de la financiación de los ejércitos, sino la de los embargos para reducir al enemigo, la de la contención del extranjero siempre sospechoso de herejía y espionaje y, por encima de todo, la de la aniquilación del dañino contrabando.

32 L. Ma Bilbao Bilbao, "El ascenso mercantil del País Vasco en los siglos XIII al XVII", en Cuadernos de Alzate, 31 (2004), pp. 159-160.

33 J.-P. Priotti, "Una conquista al revés o la penetración de los mercaderes noreuropeos y americanos en la península ibérica, 1560-1630”, en O. Mazín Gómez (ed.): México en el mundo hispánico. Zamora: El Colegio de Michoacán, 1999, t. I, p. 219. 
Ante las guerras que recorrían Europa se formaron bandos en el seno de las comunidades españolas. Unos apoyaron la política internacional de Felipe II; otros la combatieron con dineros, armas y escritos. Los valedores bilbaínos de los jesuitas se contaron entre los primeros. Muchos de ellos estaban medrando a través de la guerra y el servicio a la Corona, como constructores de barcos, proveedores de armadas, tenedores en la construcción de galeones, veedores de comercio a las órdenes del rey, etc. La trama que defiende la causa fundacional en Bilbao es la implicada en las redes que se encargan de financiar el ejército de los Países Bajos, lo cual explica que los legados iniciales que se barajaron para financiar la fundación bilbaína pertenecieran a damas relacionadas con don Juan de Austria o con los Spínola. Al otro lado del mar, en Flandes, sus corresponsales representan la defensa a ultranza del ideario contrarreformista y de la política de Felipe II en el País Bajo, cuyo ideólogo era por entonces precisamente un jesuita, Martín Antonio del Río, quien, posiblemente, pudo tener vínculos familiares con Andrés de Larrea, el gran valedor de los jesuitas en Bilbao desde Burgos. Se trataría de un entramado que cabría relacionar con el "servicio informativo" de Felipe II en Flandes del que formaban parte importantes agentes laicos y eclesiásticos de la colonia española, en la que no faltaron importantes comerciantes vitorianos y bilbaínos, dispuestos incluso a atentar contra el statúder de Holanda.

Así pues, la oligarquía mercantil bilbaína aparecía claramente dividida ante los afanes de la Compañía. En semejante tesitura, el ansiado concejo abierto que tanto se demandó desde las filas de la oposición no llegaría a celebrarse hasta el 4 de agosto del año 1600 en la iglesia de los Santos Juanes, dándose el visto bueno a la fundación ignaciana. Sin embargo, cuando el padre Acuña llegó a Bilbao a efectuar los trámites pertinentes, se encontró no sólo con la reacción de la clerecía bilbaína sino incluso con la de algún Pariente Mayor de fuerte predicamento en la Villa -es el caso de don Antonio Gómez de Butrón y Mújica-, lo que una vez más dio al traste con los planes de la Orden. De ese modo, cuatro años después, y harta de cosechar fracasos, la Compañía emprendió la política de hechos consumados que, por otra parte, pocos resultados les había dado en Vitoria cuando la pusieron en práctica en 1583. Entraron en Bilbao por Begońa de forma clandestina con el apoyo de dos regidores que actuaron totalmente a escondidas de sus propios correligionarios de Ayuntamiento, lo que da prueba del ambiente de desconfianza que, en esta materia, recorría la villa. Se instalaron en la casa habilitada para ellos, la de la Magdalena, sita en Barrencalle. Este modo de proceder provocó finalmente los serios disturbios de la mańana del martes 16 de noviembre de 1604, tan violentos que, como más tarde confesaría el corregidor al rey, "de 23 años a que administro justicia nunca tan gran alboroto y escándalo vi” ${ }^{i 4}$.

34 Aquel día, 16 de noviembre de 1604 a eso de las doce del mediodía y a toque de campana, se juntaron en la parroquia de Santiago numerosos frailes, clérigos y algunos legos, que tras un breve 
Estos sucesos, paradójicamente dieron como resultado lo que la Compañía de Jesús había venido buscando durante las siete décadas anteriores: la licencia para instalarse en la Villa ${ }^{35}$. La vehemencia de los asaltantes, ciegos de su cólera y pasión, y la inoperancia de las autoridades -el presidente del Consejo de Castilla llegó a preguntarse "que leño era corregidor en este lugar que no tuvo valor para resistir esta violencia injusta"-, desataron tal escándalo y alboroto que a punto estuvo de perderse la Villa ${ }^{36}$.

Pero, ¿quienes protagonizaron la revuelta? Sin duda, el clero fue la cabeza visible, con el prior del cabildo eclesiástico a la cabeza, junto a los de los conventos de la villa y una larga lista de hasta 70 clérigos, todos ellos beneficiados y expectantes en las iglesias de Bilbao y en otras del entorno. Cabe pensar que, como en otras muchas ciudades de la península, sus recelos nacían del temor a compartir congruas, limosnas, sermones..., fieles en definitiva, y a una competencia docente que ni de lejos el clero vizcaíno estaba en disposición de poder igualar. Pero en esta ocasión parecía haber algo más: un cierto temor al desmantelamiento de la sociedad vizcaína tradicional, a los cambios que en el propio tejido social y en la incardinación del clero mismo iban a traer los planes de la Iglesia y la Corona a través de esta nueva Orden religiosa. Eso sin olvidar cuestiones más prosaicas, que tenían que ver con el ensamblaje de la clerecía local en las actividades económicas de la zona, que se vieron alteradas en este tiempo por las necesidades militares y financieras de la Monarquía. Claro está que esos mismos temores habían ido prendiendo en otros ámbitos de la sociedad vizcaína, lo que explica que durante todos aquellos ańos los eclesiásticos se vieran apoyados por una verdadera trama civil que, mientras pudo, fue desmontando la entrada de los jesuitas en Bilbao. Esta trama civil, por lo demás, no se movió únicamente al dictado de los directores espirituales de sus almas, ni por los sólidos lazos familiares que les unían a los clérigos, sino también por intereses más terrenales; de ella se conocen al menos 76 integrantes, que se expresaron firmando algún que otro memorial contra el asentamiento de los ińiguistas en la Villa.

¿Y quiénes la formaban? En definitiva, ¿quiénes componían aquella parte de la oligarquía bilbaína tan reacia a la Compañía? Si como hemos visto los valedores de la Compañía se reclutaron entre los hombres de negocios bilbaínos que actuaban en el comercio de tránsito, como intermediarios al servicio de las grandes redes mercantiles y financieras de la época, de las que se servía el propio rey para

intercambio de palabras decidieron acudir en procesión a "rescatar el Santísimo" de la casa de la Magdalena o de Anuncibay, poco después de que los jesuitas hubieran celebrado misa tras haberse instalado en ella el día anterior.

35 Por medio del legado testamentario de don Domingo de Gorgolla que recibiría de ese modo el reconocimiento como "fundador" del colegio de San Andrés de los jesuitas de Bilbao.

36 (A)rchivum (R)omanum (S)ocietatis (I)esu, Fondo Gesuitico, Assistentia Hispaniae, Leg. 151, f. $469 \mathrm{v}$. 
mantener en pie sus intereses en el norte de Europa, los enemigos se reclutaron entre quienes controlaban la venta del hierro y la pesca de altura. Apellidos como Hormaeche, sin duda los principales tratantes del hierro en el Bilbao de entonces, o/y linajes como los Aperribay, Leguizamón, Avendaño, Butrón, etc., dueños y controladores de la infraestructura de la producción, distribución y fiscalización ferronas. El propio clero estaba muy involucrado en este engranaje, incluso cuando se trataba de actividades económicas que se conducían por las vías de la ilegalidad. La política restrictiva respecto a los extranjeros que aplicaba la Corona no fue bien entendida por amplios sectores de la población, que se involucraron también muy activamente en el mundo del contrabando. Los detractores de los jesuitas en Bilbao se contaban entre ellos, pues se sentían perjudicados por las medidas de control hacia los comerciantes extranjeros y por otras medidas de la política exterior de la Corona. Son la otra cara de la moneda. Si los valedores habían medrado con la guerra y el servicio a la Corona, los enemigos se contaban entre los perjudicados por ellos. Las levas, la confiscación de barcos, la propia guerra, les habían apartado del comercio activo de la pesca y de la caza de la ballena, pasando a depender de los extranjeros que controlaban los caladeros de Terranova y convirtiéndose en importadores de un pescado que antes exportaban. El mundo del hierro estaba en crisis y necesitaba igualmente a los extranjeros, a quienes, con independencia de su credo religioso, vendían al contado lo que previamente habían comprado al fiado. Eso sin contar con un hecho a día de hoy perfectamente constatado: la incursión de los extranjeros no sólo en la comercialización del hierro sino también en la propia siderurgia vasca. El contrabando se había convertido también a esas alturas algo más que una actividad recurrente en tiempos de penurias, y en ello contaban muy a menudo con la complicidad de las autoridades autóctonas, incluidos los eclesiásticos. Cerrando el círculo, volvemos al patronato laico. No eran grupos ajenos a él, todo lo contrario. Eran los perjudicados por las reformas eclesiásticas de la Corona, titulares y propietarios de patronatos de los que ahora eran desposeídos, sus dependientes, clérigos acomodados al sistema que no veían con buenos ojos el avance de la jurisdicción episcopal de la que se habían sustraído durante siglos; un mundo clerical en el que venían dominando órdenes muy vinculadas al mundo mercantil, en particular los franciscanos y dominicos que, como en otras zonas, se opondrán a los jesuitas por disputas doctrinales y por el temor a la competencia económica y docente, pero también por el miedo a perder su papel dentro de todo este entramado social que, en su día, llegó a describir con acierto el inquisidor Moral al señalar que "Voy entendiendo el humor desta tierra, que lo que toca a uno toca a

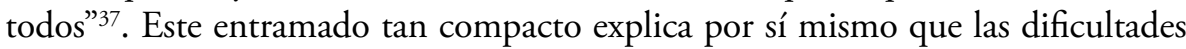
que la Compañía de Jesús tuvo para asentarse en la tierra de su fundador fueran incluso mayores que en otras geografías.

37 Porres Marijuán, “Maniobras políticas...”, pp. 1093-1098. 


\section{El complicado establecimiento de la Compañía en San Sebastián}

Dinámicas muy similares a las estudiadas en Bilbao (y Vitoria) se vivieron poco después en la vecina San Sebastián, la principal villa portuaria de la tierra del fundador de la Compañía de Jesús ${ }^{38}$. Los jesuitas en plena expansión bajo el apoyo papal, tan solo habían conseguido establecerse en Guipúzcoa en dos villas del interior: en Vergara en 1593 y en Azcoitia en 1599, ambas próximas al solar originario. La fundación de un nuevo colegio en San Sebastián desató las mismas pasiones que en Bilbao por parte de sus defensores y detractores en un proceso que, en líneas generales, dividió y alineó a gran parte de la comunidad urbana en una u otra facción, desarrollándose entre 1619 y 1627, periodo en el que el de Loyola fue canonizado (1621) y erigido en patrón de la Provincia (1622).

Las causas para el establecimiento de los jesuitas a través de la creación de un colegio se sustentaron, en un primer momento, en la necesidad de instrucción de la juventud que iba más allá al buscar, como hemos indicado, ese adoctrinamiento a través de la imposición del programa tridentino. Su actividad era relevante al tratarse de una villa abierta al exterior y bajo la amenaza de la influencia de ideas contrarias a las nuevas disposiciones de la reforma católica y a las rigurosas formas de vivencia religiosa impulsadas por la Compañía. En consecuencia, este objetivo de instrucción -incluso de una clerecía igualmente mal formada que la bilbaína- pronto fue complementado por la finalidad de hacer frente y evangelizar a los comerciantes herejes -ingleses, flamencos, escoceses o franceses- que tenían asentada su residencia en ése y en otros puertos guipuzcoanos, al igual que había sucedido en el caso de Bilbao. Pero la mera presencia de los jesuitas en la villa, activos como misioneros y predicadores en los momentos previos a la licencia de la fundación del colegio, ya espantaba a los mercaderes extranjeros que desplazaban su actividad a otros puertos menos rigurosos.

Los mecanismos de instalación de la Compañía también fueron similares en ambas villas portuarias vascas. Por una parte, no faltó en San Sebastián la obtención de un jugoso donativo para la fundación del colegio; en este caso, el legado que Domingo de Iturralde había dejado, en principio a la Villa, para fundar un convento de franciscanos, y que fue luego disputado por el convento de San Francisco. Por otra parte, en San Sebastián encontramos que las diligencias y actuaciones se realizaron con el mismo secretismo que se habían desarrollado en Vitoria y Bilbao, años atrás. Así sucedió tanto en la firma de la escritura de fundación del colegio, que conllevaba la instalación, el 2 de diciembre de 1619 -impulsada por el rector del colegio de jesuitas de Azcoitia que consiguió atraerse el favor de los

$38 \mathrm{El}$ principal trabajo sobre este tema es el capítulo realizado por Alfonso de Otazu junto a J. R. Díaz de Durana titulado "La Compañía de Jesús en el país de los vascos" en A. de Otazu y J. R. Díaz de Durana El espiritu emprendedor de los vascos, a quien seguimos en sus líneas generales en este discurso, pp. 438-554. 
junteros de San Sebastián- como en la táctica que se siguió posteriormente, en 1626, cuando se procedió a la fundación efectiva tras la obtención de la ejecutoria real, de noche y en secreto.

Pero para el asentamiento de la Compañía era necesario contar igualmente con el favor mayoritario de la comunidad urbana y eso, precisamente, fue complicado de alcanzar -de manera permanente- tanto en Bilbao como en San Sebastián, a causa de la marcada división de opiniones existente en ambas villas, que conllevaba una compleja alternancia en la disidencia interna. La renovación anual de los cargos de Regimiento, característica de los concejos vascos ${ }^{39}$, hacía difícil asegurar el perfil del Ayuntamiento y, de hecho, la ausencia de un titular o el cambio del Regimiento en enero, en San Sebastián, podían hacer bascular la balanza hacia uno u otro lado, a favor o en contra de la Compañía, como efectivamente sucedió en varias ocasiones. Esa división interna en el seno del Regimiento se plasmaba en la emisión de misivas y peticiones de amparo completamente contradictorias, que generaban confusión en la Corte y entre los patronos implicados. Además, para alcanzar el favor de la Villa, ambos grupos recurrieron a los mecanismos de toma de decisiones tradicional en las villas vascas en cuestiones de particular relevancia, al igual que en Vitoria y Pamplona: la convocatoria de concejos abiertos, populosos $-\mathrm{y}$ habitualmente tumultuosos-, en los que se congregaban los miembros de la comunidad que contaban con derechos políticos y al que acudían, en particular, los llamados vecinos especiales con voz en la Villa. Este fue precisamente uno de los escenarios en los que encontraron su hueco los contrarios a la fundación y donde se desarrolló la revuelta de 1626. En realidad, los alborotos fueron muy limitados y comedidos en 1619, subiendo en intensidad en noviembre de 1626, generándose un verdadero motín, todavía por investigar en profundidad. La historiografía ha otorgado el mayor protagonismo a una marinería, azuzada por el clero local, que basaba sus protestas en el alza de los precios de los alquileres con la llegada de los jesuitas, derivada de su conocido afán por ocupar solares urbanos, al igual que sucedió en Bilbao. La persona del proveedor Martín de Valencegui también aparece en esos escritos como el principal instigador de la algarada, al movilizar y desplazar a los marineros armados desde Pasajes a San Sebastián, que fueron cuantificados en unos mil hombres ${ }^{40}$.

Había otros escenarios de negociación donde se plantearon estas polémicas, además del estrictamente local. Por una parte, en las Juntas Provinciales se debatieron estas discusiones, mostrándose en líneas generales reacias a la instalación de los jesuitas, dado que la Compañía contaba con el decidido favor tan solo de unas

39 R. Porres Marijuán, "Oligarquías y poder municipal en las villas vascas en tiempos de los Austrias", en Revista de Historia Moderna, 19 (2001), pp. 313-354.

40 J. I. Tellechea Idígoras, Una historia turbulenta. La fundación de la Compañia de Jesús en San Sebastián (1619-1627). San Sebastian: Fundación Social y Cultural Kutxa, 1997, pp. 59-65. 
pocas villas; entre ellas ni siquiera era claro el apoyo de Vergara, donde se ubicaba uno de los dos colegios de jesuitas. Tampoco aparecen muy activos el papel del corregidor y del virrey de Navarra (que era al mismo tiempo capitán general de las tropas reales en Guipúzcoa) hasta fechas tardías: el primero probablemente porque tan solo residía temporalmente en San Sebastián, alternando su residencia en otras tres villas ${ }^{41} \mathrm{y}$ estaba supeditado al complejo juego de fuerzas entre las oligarquías provinciales; y el virrey, conde de Aguilar, apoyó sólo tibiamente a los jesuitas en 1619 enviando algunos soldados en su defensa, aunque ocho años después, el virrey conde de Castrillo actuó de manera decidida a favor de los ignacianos una vez concluido el motín, autorizando definitivamente la fundación en $1627^{42}$.

Por último, el escenario principal en el que concluyeron y se determinaron los debates fue la Corte y los Consejos de Castilla y Estado, además de la Chancillería de Valladolid. En ellos, los Idiáquez, directamente perjudicados como patronos de San Telmo, junto a los miembros más destacados de su red clientelar insertos en la trama consiliar cortesana dirigieron todas las negociaciones desde el primer momento: se trataba de los Aroztegui, los Echeverri y el secretario Juan de Insausti. Todos ellos contaban con un fuerte anclaje en la Corte y conocían a la perfección sus entresijos, los modos y las vías de actuar en ese laberinto de oficinas, por lo que consiguieron paralizar en varias ocasiones la fundación e, incluso, que se ordenara la expulsión de los jesuitas. De todas formas, el radio de influencia de los Idiáquez en la década de los veinte del siglo XVII se había reducido notablemente con relación al fuerte ascendente ejercido por don Juan en Felipe II y Felipe III, lo que no dudamos que influyó en el triunfo final de las aspiraciones de la Compañía. En la Corte, además, los jesuitas contaban con poderosos y crecientes partidarios, como fueron el conde de Bristol, el duque de Neoburgo o el conde de Castrillo, muy cercano al grupo de Olivares. Finalmente, sus opiniones calaron en el Consejo que aprobó la fundación del colegio a principios de 1626.

Por otra parte, las reacciones a la instalación de la Compañía fueron similares a las sucedidas en Bilbao, al partir la protesta en un primer momento de la clerecía contraria a la Orden ignaciana. De hecho, entre los protagonistas más activos en contra de los jesuitas nos encontramos al numeroso clero local, articulado en torno a las parroquias de Santa María y de San Vicente, al recién fundado convento de los franciscanos (en 1606 bajo patronato concejil) y al monasterio dominico de San Telmo (cuyo patrono fue don Juan de Idiáquez). Los religiosos constituyeron un activo frente contra la instalación de unos jesuitas cuya competencia temían, como se ha expuesto al inicio de este trabajo, desde el punto de vista no

41 S. Truchuelo García, "La fijación de la Audiencia del Corregimiento de Gipuzkoa en el entramado corporativo provincial (siglos XVI y XVII)", en P. Fernández Albaladejo (coord.): Monarquí, Imperio y pueblos en la España Moderna. Alicante: tomo I, AEHM, 1997, pp. 353-363.

42 Otazu, "La Compañía de Jesús...", pp. 532 y ss. y Tellechea Idígoras, Una historia turbulenta..., pp. 67-73. 
solo de la dirección espiritual de sus fieles sino también desde una perspectiva económica, de captación y distribución de limosnas, al igual que en Bilbao. Sus vínculos con las oligarquías comerciales que controlaban San Sebastián derivaban en una comunidad de intereses generada por la fuerte imbricación socio-económica, que se plasmaba en la laxitud vigente desde el punto de vista religioso frente al extranjero, que tanto sorprendió a reputados visitantes como fray Prudencio de Sandoval, en lo que Otazu ha denominado como libertad de conciencia que se vivía en San Sebastián en esas primeras décadas del siglo XVII ${ }^{43}$. De hecho, entre los contrarios más beligerantes frente a los jesuitas se encontraban los dominicos de San Telmo, que contaron con el firme apoyo de su patrono, en los años ochenta del siglo XVI, don Juan de Idiáquez y luego, en la década de 1620, su nieto, el II duque de Ciudad Real, Juan Alonso de Idiáquez y Robles. La actitud de don Juan de Idiáquez, en este caso que le afectaba directamente como patrón de San Telmo, difirió sustancialmente del favor que había otorgado a los jesuitas en los años 1590 en -la fallida por entonces-, fundación del colegio en Bilbao.

Como se ha señalado, el patrón Idiáquez y toda su parentela, contaron con el apoyo de su extensa trama clientelar que, desde la Corte, alcanzaba las instituciones provinciales y la propia Villa: en San Sebastián, actuaban dependientes de los Idiáquez como los Echeverri, los Amézqueta, los Valencegui y los Arriola, es decir, los principales linajes donostiarras que protagonizaron el rechazo a la Compañía. Estas familias habían consolidado su ascenso económico y político a partir de los años setenta del siglo XVI gracias a su integración en la intrincada y cambiante red de intereses mercantiles atlánticos, que conectaba a los comerciantes castellanos y vascos con mercaderes atlánticos ubicados en los puertos franceses, flamencos e ingleses y a través de Cádiz y Sevilla, con los puertos americano ${ }^{44}$. Como ya se ha indicado anteriormente, estos grupos se adaptaron a los nuevos contextos económicos y políticos participando, gracias al cobijo del aparato foral que establecía amplias exenciones comerciales, en un intenso contrabando que favorecía la llegada de productos de enemigos políticos y confesionales ${ }^{45}$, a través del comercio ilegal con los herejes y de la utilización de intermediarios legales ${ }^{46}$. La presencia de mercaderes extranjeros en San Sebastián permitía a este grupo en ascenso participar en ese lucrativo comercio por encima del mantenimiento de prioridades confesionales. Los sucesivos Regimientos donostiarras, dominados cada vez más por estos nuevos grupos, fueron estableciendo así un permisivo clima religioso que favorecía la estancia de mercaderes extranjeros, casi como naturales, siempre

43 Otazu, passim.

44 R. Grafe, Entre el mundo ibérico y el Atlántico. Comercio y especialización regional, 1550-1650. Bilbao: Diputación Foral de Bizkaia, 2005.

45 Priotti, “Una conquista al revés...”, pp. 207-230.

46 P. Croft, "Trading with the Enemy (1585-1604)", en The Historical Journal, $32 / 2$ (2011), pp. 281-302. 
que no hubiera una exteriorización ostentosa de la filiación a confesiones consideradas heréticas. En esta misma línea, el desempeño del cargo de la familiatura de la Inquisición por parte de miembros de estas familias, como fueron el capitán Juanes de Amézqueta o el mismo Arano de Valencegui, principales enemigos de los jesuitas, permitió a estos linajes ejercer una fuerte influencia sobre el clero local, al ser ellos quienes tenían encomendada la vigilancia religiosa en esos puertos, sobre el clero y sobre las actividades comerciales; esa libertad de conciencia de la que habla Otazu sería preservada por los familiares de la Inquisición al evitar las denuncias de muchos mercaderes extranjeros ${ }^{47}$. En este sentido, dada la exención de jurisdicción que gozaban los jesuitas frente a la Inquisición, su asentamiento en San Sebastián haría peligrar la tutela ejercida por los familiares sobre los extranjeros, lo que era un elemento más que se sumaba a los argumentos contrarios a la instalación de la Compañía.

En definitiva, esta facción en ascenso, claramente enemiga de la firme ortodoxia desarrollada por los jesuitas, estaba constituida por comerciantes vinculados al gran comercio y, en particular, al hierro, como sucedía en Bilbao, necesario para la construcción naval orientada a esos tránsitos mercantiles y a la fábrica de galeones para la Armada real, que constituía una de sus principales actividades. Además, estas familias consolidaron su ascenso gracias a su participación en el servicio real, que les generó prestigio en sus comunidades, mejores enlaces matrimoniales y el acceso a la gracia real y a nuevos títulos ${ }^{48}$. En el caso donostiarra, a diferencia del bilbaíno, uno de los protagonistas principales del rechazo a los jesuitas, Martín Arano de Valencegui, ejerció sucesivamente los cargos de proveedor general de las armadas, pagador de la gente de guerra de la provincia, y veedor y contador de la fábrica de galeones, que le daban enorme influencia sobre la población a la hora de realizar levas, en particular de marinería, y de acceder y distribuir metal precioso con el que pagar los salarios y el aprovisionamiento del ejército y la armada.

El otro grupo enfrentado en San Sebastián fue el de las oligarquías favorables a la instalación de los jesuitas. Se trataba de linajes antiguos, asentados desde el siglo XV, y que habían monopolizado el gobierno hasta los años setenta del siglo $\mathrm{XVI}$ en que comenzaron a desarticularse los tráficos comerciales: los nombres más característicos eran los Aguirre, Engómez, Santiago o Del Río. Al igual que el anterior grupo, eran asimismo armadores y comerciantes, vinculados a las pesquerías de Terranova, también al servicio de la Armada, y que habían participado activamente en la expansión marítima en el Mediterráneo y luego en el Atlántico, pero estaban directamente vinculados a un comercio más tradicional, dirigido desde Burgos hacia Francia, y que progresivamente fueron alejándose del comer-

47 Otazu, “La Compañía de Jesús...”, pp. 501-503.

48 J. Ma Imízcoz Beunza, “Parte II. Hacia nuevos horizontes: 1516-1700”, en M. Artola (ed.), Historia de Donostia-San Sebastián. Hondarribia: Nerea, 2000, pp. 87-180. 
cio controlado por unos extranjeros con los que se había quebrado la confianza y de las rutas que éstos estaban monopolizando. A ellos se fueron incorporando igualmente algunos nuevos miembros de las oligarquías opuestos a los jesuitas: es el caso del capitán Miguel de Oquendo en el siglo XVI -cuya interesante biografía es relatada por Otazu e Imízcoz-, primero muy enfrentado a esta facción y, en particular, a alguno de sus líderes -como los Aguirre- pero que, finalmente, en un proceso de aristocratización, terminó emparentando con miembros de antiguos linajes con sabor banderizo, como eran los Lazcano y los San Millán, integrándose en esa facción más conservadora ${ }^{49}$.

Este grupo tradicional, defensor de los jesuitas, fue el principal promotor de una dinámica de cierre estamental activa en el ámbito castellano, que estaba directamente vinculada a la prevención frente al numeroso extranjero ${ }^{50}$, de manera acusada desde el último cuarto del siglo $\mathrm{XVI}^{51}$ y que afectaba a todos los foráneos pero, especialmente, a los provenientes de territorios sospechosos de comulgar con confesiones consideradas heréticas. Estas dinámicas de segregación racial y religiosa impulsadas por esta facción de las oligarquías urbanas y provinciales, tenían como mecanismo principal la demostración de la limpieza de sangre, condición restrictiva fomentada por el propio Felipe II durante todo su reinado y que continuó entre 1600 y 1630 en que se produjo el asentamiento de la Compañía de Jesús en Bilbao y en San Sebastián ${ }^{52}$. Este requisito legal permitía establecer el principio de exclusión de la vida política de minorías provenientes de razas consideradas impuras a ojos católicos y que se creía que profesaban todavía en secreto confesiones heréticas, como podían ser los cristianos nuevos o judeo-conversos y, asimismo, los extranjeros con un origen potencialmente herético, como eran los ingleses, franceses y flamencos residentes en las villas de Bilbao y San Sebastián ${ }^{53}$.

49 Otazu, “La Compañía de Jesús...”, pp. 476-489 e Imízcoz Beúnza, “Parte II...”, pp. 147149.

50 Los extranjeros estaban muy presentes en la zona cantábrica. O. Rey Castelao, "Los extranjeros en la cornisa cantábrica durante la Edad Moderna”, en M. ${ }^{a}$ B. Villar García; P. Pezzi Cristóbal (dirs.), Los extranjeros en la España moderna Málaga: Universidad de Málaga, 2003, t. II, pp. 24-25.

51 A. Domínguez Ortiz, Los extranjeros en la vida española durante el siglo XVII y otros artículos. Sevilla: Universidad de Sevilla, 1996.

52 J. I. Gutiérrez Nieto, "La limpieza de sangre", en E. Martínez Ruiz; M. P. Pi Corrales (eds.): Instituciones de la España Moderna. Vol. 2: Dogmatismo e intolerancia. Madrid: Actas, 1997, pp. 3443; A. A. Sicroff, Los estatutos de limpieza. Controversias entre los siglos XV y XVII. Madrid: Taurus, 1985 y J. Hernández Franco, Sangre limpia, sangre española: la limpieza de sangre. Madrid: Cátedra, 2011.

53 M. Torres Arce, "Swimming against the Tide: The Entry of Jews in Spain. Religious Mobility, Social Control and Integration at the End of the Ancient Régime", en T. G. Fehler et alii (eds.): Religious diaspora in Early Modern Europe: Strategies of Exile, Londres: Pickering and Chatto, 2014, pp. 19-31. 
Precisamente, las villas vascas que nos ocupan, al ser centros de intensa recepción y tránsito de extranjeros, sufrieron muy vivamente esta polémica en torno a la exclusión de foráneos por causas no solo políticas -ante el miedo al enemigo o posible espía- sino principalmente confesionales, lo que iba en detrimento de compartidos intereses económicos. Parte de las elites urbanas, en particular la facción más tradicional favorable a la instauración de los jesuitas, se mostró de acuerdo con el refuerzo de los procesos de control en la residencia y los avecindamientos, siguiendo las líneas propuestas por Felipe II, consolidándose así los principios de nobleza, limpieza y catolicidad, como elementos singularizantes de la comunidad local y de sus oligarquías ${ }^{54}$; así, en Castilla el término vizcaíno llegó a ser sinónimo de cristiano viejo y de pureza religiosa. Es necesario no olvidar que, en el caso de las provincias marítimas, estos requisitos restrictivos se encontraban directamente vinculados a la primacía que la noción de hidalguía universal o limpieza colectiva tenía para el mantenimiento de la naturaleza política privilegiada de esos territorios vascos en el contexto castellano ${ }^{55}$ y de la exención fiscal que gozaban en el marco de la Monarquía Hispánica ${ }^{56}$. Por ello, las políticas locales sobre el avecindamiento y, lo que es más importante, sobre el acceso a los oficios de gobierno y justicia, tendieron a prohibir, de hecho, el acceso de los extranjeros a los puestos municipales ${ }^{57}$ : la obligación de demostrar su limpieza de sangre, la prohibición de disponer de vivienda o casa en propiedad o alquilada así como la interdicción de alojar a compatriotas huéspedes -cuya lealtad era más que dudosa $-{ }^{58}$ se erigieron en condicionamientos que impedían a los extranjeros disfrutar del derecho de residencia que les permitía (junto a otros requisitos socio-culturales, estamentales, lingüísticos y económicos) adquirir la condición de vecinos con plenos derechos políticos ${ }^{59}$. En este contexto de cierre estamental

54 S. Truchuelo García, "Comercio y ortodoxia en los puertos vascos. ¿Fronteras de agua?, en M.-R. García Hurtado; O. Rey Castelao (eds.): Fronteras de agua. Las ciudades portuarias y su universo cultural (siglos XIV-XXI). Santiago de Compostela: Universidade de Santiago de Compostela, 2016, pp. 115-130.

55 P. Fernández Albaladejo y J. M. ${ }^{a}$ Portillo, "Hidalguía, Fueros y Constitución política: el caso de Guipúzcoa", en Hidalgos \& Hidalguía dans l'Espagne des XVI-XVIIIe siècles. París: CNRS, 1989, p. 152.

56 S. Truchuelo García, "Extranjería y fronteras urbanas en el norte de España. ¿Una integración conflictiva?", en V. Favarò, M. Merluzzi y G. Sabatini (eds.): Procesos y prácticas de integración y conflictos entre Europa y América (siglos XVI-XX). Madrid: FCE, Red Columnaria, 2017, pp. 403 416.

57 En 1557 se prohibió a los franceses ocupar cargos concejiles, como potenciales enemigos y luteranos. M. Boeglin, "Luteranos franceses en la Espańa de los Austrias. Aspectos culturales de un conflicto religioso", en La cultura del otro. Sevilla: Universidad de Sevilla, 2006, pp. 118-132.

58 Las mismas normas se aplicaban a ingleses, flamencos y a portugueses (I. Reguera Acedo, "Todos cuatro costados de limpia sangre. Excluidos y marginados: la defensa de la hidalguía universal y de la raza”, en E. García Fernández (ed.): Bilbao, Vitoria y San Sebastián, pp. 497-498).

59 S. Truchuelo García, Tolosa en el Edad Moderna. Organización y gobierno de una villa guipuz- 
y de limpieza de sangre vinculada a la ortodoxia católica se insertaba la labor de los jesuitas y la opinión de quienes apoyaban su implantación en las villas vascas.

De todos modos, pese a la consolidación desde finales del reinado de Felipe II y durante las primeras décadas del siglo XVII de estos requisitos restrictivos que ya habían comenzado a regularse desde principios del siglo XVI, los extranjeros asentados en esas mismas villas costeras continuaron la tendencia ya existente a ir insertándose lentamente en las redes comerciales a través de la consolidación no sólo de vínculos económicos sino también familiares. La transgresión de las propias normas locales por parte de las mismas oligarquías urbanas encargadas de su cumplimiento - de la mano de sus alcaldes ordinarios- permitió que ingleses, franceses y flamencos -entroncados con familias locales ilustres, integrantes de las mismas oligarquías que controlaban los avecindamientos-, bien se mantuvieran en el territorio como meros residentes bien, transcurrido algún tiempo, accedieran a los Regimientos y se integraran plenamente en las comunidades urbanas ${ }^{60}$. En definitiva, la facción de esas mismas elites urbanas que se mostró contraria a la instauración de la Compañía tendió a mantener una mayor laxitud, tolerancia y flexibilidad en la ejecución práctica de las normas locales y provinciales sobre el avecindamiento, defendiendo a ultranza la autoridad de los alcaldes ordinarios frente a las instituciones provinciales y permitiendo la residencia de mercaderes extranjeros, para que no perjudicara el dinamismo económico aconfesional que estaba en fase de construcción y del que se estaban beneficiando estos nuevos grupos.

Los mayores controles teóricos se establecieron frente a aquellos grupos que podían contaminar, de manera más evidente, la limpieza de sangre y la catolicidad de guipuzcoanos y vizcaínos, como eran los comerciantes y financieros portugueses judeo-conversos, vinculados a las colonias sefardíes de Bayona y Ámsterdam, que participaban en el lucrativo contrabando de moneda por los puertos cantábricos y los pasos pirenaicos ${ }^{61}$. Desde principios del siglo XVII se intensificaron los controles sobre el cumplimiento exterior de la ortodoxia católica de esos recién $\operatorname{llegados}^{62}$, coincidiendo con la llegada de los jesuitas a Bilbao y, luego, a San

coana. Tolosa: Lizardi Kultur Elkartea, 2006, pp. 121-144.

60 Estudiamos el caso de los ingleses a finales del siglo XVI en S. Truchuelo García, "Heresy and Comercial Exchanges in Early Modern Northern Spain”, en J. Spohnholz y G. K. Waite (eds.): Exile and Religious Identity, 1500-1800. Londres: Pickering \& Chatto, 2014, pp. 127-140.

61 J. I. Israel, La judería europea en la era del mercantilismo (1550-1570). Madrid: Cátedra, 1992, pp. 80-82; B. J. López Belinchón, "Sacar sustancia al reino. Comercio, contrabando y conversos portugueses, 1621-1640”, en Hispania, LXI/3, 209, 2001, pp. 1017-1050 y J. A. Carrasco Vázquez, "Contrabando, moneda y espionaje (el negocio del vellón: 1606-1620)", en Hispania, LVII/3, 197, pp. 1081-1105.

62 Las investigaciones se reprodujeron en ese período expulsándose, principalmente a judeoconversos y cristianos nuevos. A. Angulo Morales, "El control y la persecución de los mercaderes portugueses en la Castilla de la primera mitad del siglo XVII", en E. García Fernández (ed.): Exclusión, racismo y xenofobia en Europa y América. Bilbao: UPV-EHU, 2002, pp. 179-203. 
Sebastián. Pero la supervisión de las residencias y de los avecindamientos continuó recayendo en las autoridades locales, lo que concedía un amplio margen de maniobra a esas oligarquías y una adaptación efectiva de las normas a sus propios intereses, cuando lo creían conveniente. Las vías de colaboración y, en particular, el intenso contrabando desarrollado a través de la activación de estas redes comerciales transnacionales -gracias al control foral sobre la legalidad del comercio y a la connivencia incluso de los oficiales reales- ${ }^{63}$ seguían plenamente operativas, como muestra el hecho de que durante el motín de 1626 se enarbolara en San Sebastián una bandera holandes ${ }^{64}$. De hecho, las intensas acusaciones de participación de las comunidades vascas en este comercio con los herejes y de connivencia de las autoridades concejiles $-\mathrm{y}$ reales- en el intenso contrabando de moneda -tanto en la saca de plata como en la introducción de vellón falsificado- se intensificaron en el contexto de la polémica de la instauración de la Compañía de Jesús en San Sebastián. La llegada a Guipúzcoa del projesuita licenciado Jerónimo de Avellaneda y Manrique, justo días después de los altercados contra la Compañía en 1626, contribuyó a determinar la conclusión de la polémica y favoreció la exhaustiva investigación del comisario extraordinario -que destapó el intenso contrabando y la connivencia de alcaldes y mercaderes locales- ${ }^{65}$ así como el establecimiento definitivo de la Compañía de Jesús de la mano del virrey de Navarra.

\section{RECAPITULACIÓN FINAL}

En definitiva, los debates internos en el seno de las elites gobernantes en las villas vascas sobre la instauración de los jesuitas en los puertos costeros fueron un claro espejo de las discrepancias paralelas existentes entre las oligarquías locales sobre la incorporación o segregación de estos grupos de foráneos y, en definitiva, sobre la permeabilidad de las vías de exclusión de estos extranjeros, en particular los procedentes de tierras no católicas. La readaptación económica vivida a partir de la década de los setenta del siglo XVI entre los principales linajes bilbaínos y guipuzcoanos determinó la consolidación de dos facciones de poder enfrentadas en el seno de ambas corporaciones urbanas, cuyas posturas divergentes quedaron plasmadas con motivo del establecimiento de la Compañía de Jesús. Mientras que

63 Véanse algunos ejemplos de esta connivencia con el contrabando en Vizcaya y Guipúzcoa de finales del siglo XVI y durante los años veinte del siglo XVII en S. Truchuelo García, "Restablecer la legalidad en la Monarquía de los Habsburgo: actuaciones frente al contrabando en el País Vasco costero (1585-1598)", en L. Antonielli y S. Levati (eds.): Contrabbando e legalità: polizie a difesa di privative, diritti sovrani e pubblico erario. Milán: Rubbettino, 2016, pp. 23-57 y S. Truchuelo García, Contrebandiers de monnaie et autorités locales sur les côtes basques au début du XVII siècle, en Criminocorpus. Puesto en el 17/ 02/2014. Disponible en http://criminocorpus.revues.org/2666 [consultado el 12-11-2017].

64 Otazu, "La Compañía de Jesús...", p. 522.

65 Todo el expediente se encuentra en AHN, Consejos Suprimidos, legajo 30283, expediente 2. 
una se mostró más favorable al mantenimiento de los vínculos comerciales con los nuevos directores de las rutas económicas internacionales, sin atender expresamente a solidaridades confesionales, raciales y estamentales, en la otra facción primaba, por encima de estas cuestiones, la prevalencia de intereses económicos más tradicionales, vinculados además a la preservación de una marcada defensa de la ortodoxia católica. La vinculación de ambas facciones con sectores, también enfrentados, del clero local, contribuye a identificar algunas claves de las complejas disidencias planteadas en las villas vascas, no solo en el ejercicio de la influencia espiritual y en el control sobre la economía donativa de sus gentes sino en la orientación de sus propias actividades y en sus relaciones interiores y exteriores en el marco de una Monarquía Hispánica inserta en un determinante contexto cada vez más global. 